\title{
The helminth parasites of the two bufonid toads, European Common Toad, Bufo bufo (Linnaeus, 1758) and European Green toad, Bufo (Pseudepidalea) viridis Laurenti, 1768 (Anura: Bufonidae), collected from Denizli Province, Inner-West Anatolia Region, Turkey
}

\author{
S. DÜŞEN \\ Pamukkale University, Faculty of Arts and Sciences, Department of Biology, Kinikli Campus, \\ Kinikli 20017 Denizli, Turkey, E-mail:sdusen@pamukkale.edu.tr,serdar2290@yahoo.com
}

\begin{abstract}
Summary
In this research, two bufonid toad species (Bufo bufo and Bufo (Pseudepidalea) viridis) were collected in Denizli province (Inner-west Anatolia Region - the eastern part of Aegean Region) Turkey between 2006 and 2009 and examined first time for helminths. Of 6 Bufo bufo, 5 (97.87\%) were infected with one or more helminths, of 47 Bufo viridis $46(87.91 \%)$ were infected with one or more helminths. The helminth fauna of Bufo bufo included 5 species of which were 4 species of nematodes (Rhabdias bufonis, Oswadocruzia filiformis, Cosmocerca ornata, and Oxysomatium brevicaudatum), and 1 species of acanthocephalan (Acanthocephalus ranae). The helminth fauna of Bufo (Pseudepidalea) viridis comprised 7 species with 1 species of monogenean (Polystoma viridis), 1 species of cestoda (Nematotaenia dispar), and 5 species of nematodes (R. bufonis, O. filiformis, C. ornata, C. commutata, and $O$. brevicaudatum). $R$. bufonis, $O$. filiformis, $C$. ornata, and $O$. brevicaudatum were observed in both bufonid toads.
\end{abstract}

Keywords: Amphibians; Bufo bufo; Bufo (Pseudepidalea) viridis; Denizli; European common toad; European green toad; helminths; Turkey

\section{Introduction}

The European common toad Bufo Bufo (Linnaeus, 1758) lives in damp, rocky-pebbly areas with sparse vegetation, or in forest grounds. Fossorial, sheltering under the rocks or in soil. Forages nocturnally, move the small ponds or pools for breeding. European green toad, Bufo viridis (Laurenti, 1768) recently placed into Genus Pseudepidalea by Frost et al. (2006), but there is continuing disagreement over the use of the generic name Pseudepidalea over the use of Bufo (IUCN, 2011). In this study, both generic names are used. Bufo (Pseudepidalea) viridis (Laurenti, 1768) is a nocturnal species shelters in the daytime under stones or within subterranean burrows in garden or open fields, goes to water only for breeding. In Turkey, B. viridis is widespread in suitable biotopes. (Baran \& Atatür, 1997; Budak \& Göçmen, 2008).

The previous reports of parasites in European common toad (B. bufo) from Turkey is recorded by Yildirımhan et al. (1997a) and Düșen et al. (2010a) from north-western parts of Turkey. Yildırımhan \& Karadeniz (2007) reported helminths of $B$. bufo from northeast of Turkey; Düşen \& Oğuz (2010) recorded helminths of B. bufo Middle Black Sea Region of Turkey.

To our knowledge, the first helminthological study in $B$. viridis was reported by Schad et al. (1960) in Turkey, Schad et al. (1960) recorded 5 nematode species in $B$. viridis. Other helminthological studies on European green toad (B. viridis) published by Yildırımhan (1999a) and Düşen et al. (2010a) from north-western Turkey. Also, Düşen (2003) recorded five helminth species from Southwestern Turkey.

So far, there has been no published study on helminths of European common toad (Bufo bufo), and European green toad (Bufo (Pseudepidalea) viridis) from Denizli province, and its vicinity (Inner-west Anatolia Region - the eastern part of Aegean Region) in Turkey. This is the first helminthological research, which has been done in this mentioned geographic area.

\section{Materials and methods}

Fifty-three anurans representing two species were collected between 2006 - 2009 years in Denizli province and its vicinity. Six B. bufo $(2 \hat{\jmath} \widehat{\jmath}, 4$ 웅, mean \pm SD snout-vent length (SVL) of B. bufo specimens was $78.24 \pm 11.67 \mathrm{~mm}$, with a range from 65.90 to $91.34 \mathrm{~mm}$ ); Forty-seven $B$.

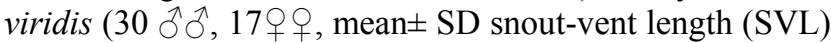
of $B$. viridis specimens was $67.78 \pm 15.83 \mathrm{~mm}$, with a range from 27.16 to $86.07 \mathrm{~mm}$ ) were collected by dip net and hand from the suitable habitats in Denizli province 
$\left(38^{\circ} 29^{\prime}-38^{\circ} 52^{\prime} \mathrm{N}-28^{\circ} 38^{\prime}-30^{\circ} 05^{\prime} \mathrm{E}\right)$, within $48 \mathrm{hr}$, toads were overdosed in ether-filled glass containers.

The body cavity was opened by a longitidunal ventral incision, alimentary canal was excised and seperated into stomach, small intestine, large intestine and rectum. The contents of each part and other organs (lungs, liver, gall bladder, kidneys and urinary bladder) were each mixed with $0.5 \%$ saline solution and were poured into petri dishes for examination under a stereomicroscope. The muscles, plus portions of peritoneum and spinal cord, were teased out with needles and examined under a stereomicroscope. Trematodes were immobilized by heat, fixed, and stored in $70 \%$ ethanol. Nematodes were straightened by heat, fixed, and stored in $70 \%$ ethanol with $5 \%$ glycerol. Acanthocephalans were relaxed in saline and heat-fixed under slight coverslip pressure in warm alcohol-formalinacetic acid. Monogenean, cestoda and acanthocephalans were stained with aceto-carmine, dehydrated, cleared in cedar oil, and mounted in Entellan ${ }^{\circledR}$; nematodes were cleared in glycerol and examined. Intensities are presented as mean values $( \pm \mathrm{SD})$ followed by the range.

Voucher specimens of parasites were deposited in the Ege University, Museum of Zoology, Izmir, Turkey (ZDEUHEL); host specimens were deposited in Pamukkale University Faculty of Arts and Sciences and Department of Biology, Denizli, Turkey.

\section{Results and discussion}

\section{Bufo bufo (Linnaeus, 1758)}

Six specimens $(2 \hat{\jmath} \hat{\jmath}, 4 ㅇ+q)$ were collected between $2006-$ 2009 years from Denizli province, Turkey (38 $29^{\prime}-38^{\circ} 52^{\prime}$ $\left.\mathrm{N}-28^{\circ} 38^{\prime}-30^{\circ} 05^{\prime} \mathrm{E}\right)$.

Family: Rhabdiasidae

Rhabdias bufonis (Schrank, 1788) Stiles and Hassal, 1905 Prevalence, intensity and range: Hosts infected, 1 of 6 (16.66 \%); mean intensity 1 (1). Rhabdias bufonis is known from various amphibian species including, Bufo sp., Rana sp., Pelobates sp., Bominator sp., Anguis fragilis (Yamaguti, 1961; Düşen et al., 2010b); Bobina bombina (Grabda-Kazubska \& Lewin, 1989; Yıldırımhan et al., 2001a); Pelodytes caucasicus (Y1ldırımhan et al., 2009), $R$. esculenta (Buchvarov, 1977; Kuc \& Sulgostowska, 1988b); R. temporaria, R. arvalis (Kuc \& Sulgostowska, 1988b; Cedhagen, 1988); B. viridis (Buchvarov et al., 1975; Buchvarov, 1977; Yıldırımhan, 1999a); R.. dalmatina (Buchvarov et al., 1975; Buchvarov, 1977; Düşen et al., 2009); B. variegata, P. syriacus (Buchvarov, 1977); $R$. ridibunda (Yıldırımhan et al., 1996; Yıldırımhan et al., 1997a; Düşen \& Öz, 2006; Sağlam \& Arıkan, 2006), $R$. camerani (Y1ldırımhan et al., 2006), R. macrocnemis (Y1ldırımhan et al., 2006b). The geographic range of this specis Europe, Siberia, China, Canada, U.S.A. (Yamaguti, 1961).

Specimens deposited: ZDEU HEL-5/2009 (2 Slides)
Family: Molineidae

Oswaldocruzia filiformis (Goeze, 1782) Travassos, 1917

Prevalence, intensity and range: Two of 6 hosts infected $(33.33 \%, 1.50 \pm 0.70 \mathrm{SD}, 1-2)$.

Oswaldocruzia filiformis is recorded from various amphibian and reptile species, including $S$. salamandra (Buchvarov, 1977), T. alpestris and T. karelini (Buchvarov, 1977; Cedhagen 1988; Kirin \& Buchvarov, 2002), $T$. vulgaris (Buchvarov, 1977; Shimalov et al., 2001), Triturus vittatus (Y1ldırımhan, 2008), Bombina bombina and $B$. variegata (Buchvarov, 1977, Kirin \& Buchvarov, 2002), B. regularis (probably $B$. viridis) (Schad et al., 1960), $B$. viridis (Buchvarov, 1977; Y1ldırımhan, 1999; Shimalov \& Shimalov, 2001; Düşen et al., 2010a; Düşen \& Oğuz, 2010), P. caucasicus (Yildirımhan et al., 2009), H. arborea (Buchvarov, 1977; Y1ldırımhan et al., 2006c), R. camerani, $R$. dalmatina, (Batchvarov et al., 1975; Buchvarov, 1977; Kirin \& Buchvarov, 2002; Düşen et al., 2009), R. kurtmuelleri (Hristovski et al., 2006), R. macrocnemis (Schad et al., 1960; Yıldırımhan et al., 1997b; Yıldırımhan et al., 2006b), R. ridibunda (Buchvarov, 1977; Yıldırımhan et al., 1996; Batchvarov et al., 1975; Kirin \& Buchvarov, 2002; Y1ldırımhan et al., 2005a; Sağlam \& Arıkan 2006; Düşen \& Oğuz, 2010), Rana temporaria, (Buchvarov, 1977; Cedhagen, 1988; Kirin \& Buchvarov, 2002), R. graeca (Božkov \& Stojkova, 1970; Buchvarov, 1977), Lacerta agilis, (Sharpilo et al., 2001; Shimalov et al., 2000; Mihalca et al., 2007), L. trilineata (Y1ldırımhan, 1999b), L. viridis (Biserkov \& Kostadinova, 1998; Yıldırımhan, 1999b; Kirin, 2002a; Borkovcová \& Kopřiva, 2005), L. vivipara (Shimalov et al., 2000), Anguis fragilis (Schad et al., 1960; Bertman \& Okulewicz, 1987; Shimalov et al., 2000; Borkovcová \& Koprriva 2005; Düşen et al, 2010b), Zootoca vivipara (Sanchis et al., 2000), N. natrix (Bertman \& Okulewicz, 1987; Shimalov \& Shimalov, 2000; Kirin 2002b) and V. berus (Shimalov \& Shimalov, 2000).

Schad et al. (1960) first time reported O. filiformis in Bufo regularis (probably $B$. viridis) and $R$. macrocnemis from Turkey. This species were observed in small and large intestines from two bufonid toads species in this study. The geographic range of $O$. filiformis includes Europe and Asia (Yamaguti, 1961).

Specimens deposited: ZDEU HEL-6/2009 (2 Slides)

\section{Family: Cosmocercidae}

Cosmocerca ornata (Dujardin, 1845)

Prevalence, intensity and range: Two of 6 hosts were infected $(33.33 \%, 10.50 \pm 4.94 \mathrm{SD}, 7-14)$.

There are several papers reporting $C$. ornata from many species of amphibians and reptiles, including Bufo, Hyla, Rana, Triturus (Yamaguti, 1961), T. alpestris (Walton, 1933; Buchvarov, 1977; Shimalov et al., 2000), T. cristatus (Walton, 1933; Shimalov et al., 2001) T. vulgaris (Shimalov et al., 2001), Bombina bombina, (Buchvarov, 1977; Grabda-Kazubska \& Lewin, 1989), B. variegata 
Table 1. Prevalence, intensity, infection sites and range of helminths in Bufo bufo and Bufo (Pseudepidalea) viridis

\begin{tabular}{|c|c|c|c|c|c|c|}
\hline Identified helminth group & $\begin{array}{c}\text { Developmental } \\
\text { stage }\end{array}$ & Host species & $\begin{array}{c}\text { Site } \\
\text { of infection }\end{array}$ & $\begin{array}{c}\text { No. } \\
\text { of infected } \\
(\%)\end{array}$ & $\begin{array}{c}\text { Mean Intensity } \\
( \pm \text { SD })\end{array}$ & Range \\
\hline \multicolumn{7}{|l|}{ POLYSTOMATIDAE } \\
\hline Polystoma viridis & Adult & B. viridis & UB & $8(17.02)$ & $4.50 \pm 2.72$ & $1-8$ \\
\hline \multicolumn{7}{|l|}{ NEMATOTAENIIDAE } \\
\hline Nematotaenia dispar & Adult & B. viridis & LI, SI & $10(21.27)$ & $1.90 \pm 0.99$ & $1-4$ \\
\hline \multicolumn{7}{|l|}{ RHABDIASIDAE } \\
\hline Rhabdias bufonis & Adult & $\begin{array}{l}\text { B. bufo } \\
\text { B. viridis }\end{array}$ & $\mathrm{L}$ & $\begin{array}{c}1(16.66) \\
24(51.06)\end{array}$ & $\begin{array}{c}1 \\
8.87 \pm 11.89\end{array}$ & $\begin{array}{c}1 \\
1-53\end{array}$ \\
\hline \multicolumn{7}{|l|}{ MOLINEIDAE } \\
\hline Oswaldocruzia filiformis & Adult & $\begin{array}{l}\text { B. bufo } \\
\text { B. viridis }\end{array}$ & SI & $\begin{array}{l}2(33.33) \\
15(31.91)\end{array}$ & $\begin{array}{l}1.50 \pm 0.70 \\
4.60 \pm 5.06\end{array}$ & $\begin{array}{l}1-2 \\
1-10\end{array}$ \\
\hline \multicolumn{7}{|l|}{ COSMOCERCIDAE } \\
\hline Cosmocerca commutata & Adult & B. viridis & LI, SI, R & $14(29.78)$ & $10.28 \pm 9.65$ & $1-30$ \\
\hline Cosmocerca ornata & Adult & $\begin{array}{l}\text { B. bufo } \\
\text { B. viridis }\end{array}$ & LI, SI, R & $\begin{array}{c}2(33.33) \\
23(48.93)\end{array}$ & $\begin{array}{l}10.5 \pm 4.95 \\
8.91 \pm 7.49\end{array}$ & $\begin{array}{l}7-14 \\
1-28\end{array}$ \\
\hline Oxysomatium brevicaudatum & Adult & $\begin{array}{l}\text { B. bufo } \\
\text { B. viridis }\end{array}$ & LI, SI & $\begin{array}{c}3(50.0) \\
18(38.29)\end{array}$ & $\begin{array}{c}2.33 \pm 1.52 \\
14.22 \pm 11.52\end{array}$ & $\begin{array}{c}1-4 \\
2-40\end{array}$ \\
\hline \multicolumn{7}{|l|}{ ECHINORHYNCHIDAE } \\
\hline Acanthocephalus ranae & Adult & B. bufo & SI & $3(50.0)$ & $18.30 \pm 11.54$ & $5-25$ \\
\hline
\end{tabular}

L - Lung, LI - Large intestine, M - Mesentery, R - Rectum, SI - Small intestine; UB - Urinary Bladder

(Buchvarov, 1977; Grabda-Kazubska \& Lewin, 1989; Kirin \& Buchvarov, 2002), B. viridis (Batchvarov et al., 1975; Buchvarov, 1977; Vashetko \& Siddikov,1999; Masshaii, 2005; Düşen et al., 2010a, 2010b), Pelodytes caucasicus (Yıldırımhan et al., 2009), H. arborea (Buchvarov, 1977, Yıldırımhan et al., 2006c), P. syriacus (Shimalov et al., 2000), R. esculenta (Walton, 1933; Buchvarov, 1977), $R$. arvalis (Cedhagen, 1988; Kuc \& Sulgostowska, 1988b), R. temporaria, (Walton, 1933; Buchvarov, 1977; Kuc \& Sulgostowska, 1988b), R. graeca (Božkov \& Stojkova, 1970; Buchvarov, 1977), R. holtzi (Yıldırımhan et al., 2006b), R. macrocnemis (Yıldırımhan et al., 2006b; Düşen, 2007), $R$. ridibunda (Batchvarov et al., 1975; Buchvarov, 1977; Kuc \& Sulgostowska, 1988a; Masshaii et al., 2000; Kirin \& Buchvarov, 2002; Kirin, 2003a, b; Yildırımhan et al., 2005a; Düșen \& Öz, 2006; Düşen et al., 2010a, 2010b), R. camerani (Yıldırımhan et al., 2006a; Düşen, 2007), Chiasmocleis capixaba (Van Sluys et al,. 2006) and A. fragilis (Shimalov et al. 2000; Düşen et al., 2010b).

Schad et al. (1960) first time recorded C. ornata in B. viridis, $R$. macrocnemis and $R$. ridibunda from Turkey. Cosmocerca ornata was observed from two bufonid species intestines in this study. The geographic range of $C$. ornata New and Old Worlds (Baker, 1987).

Specimens deposited: ZDEU HEL-7/2009 (2 Slides)
Oxysomatium brevicaudatum (Zeder, 1800) Railliet and Henry, 1916

Prevalence, intensity and range: Three of 3 hosts were infected $(50 \%, 2.33 \pm 1.52 \mathrm{SD}, 1-4)$.

Oxysomatium brevicaudatum was reported from different hosts of amphibians and reptiles in Europe and Asia, including Bombina, Bufo, Hyla, Pelobates, Rana, Salamandra (Yamaguti, 1961), S. salamandra, S. atra, Pseudotriton ruber and B. bombina (Walton, 1933), Triturus vittatus, T. karelinii (Yıldırımhan, 2008), P. syriacus (Yıldırımhan et al., 1997a; Yıldırımhan \& Bursey, 2010), B. viridis (Walton, 1933; Schad et al., 1960; Buchvarov, 1977; Yıldırımhan, 1999a; Düşen et al., 2010b), B. regularis (probably $B$. viridis) (Schad et al.,1960), H. arborea (Walton, 1933), $R$. dalmatina (Buchvarov, 1977; Düşen et al., 2009), R. graeca (Božkov \& Stojkova, 1970; Buchvarov, 1977), R. esculenta (Walton, 1933), R. kurtmuelleri (Hristovski et al., 2006), $R$. macrocnemis (Schad et al., 1960), R. ridibunda (Schad et al., 1960, Kirin \& Buchvarov, 2002; Y1ldırımhan et al., 2005a; Sağlam \& Arıkan, 2006; Düşen et al., 2010a; Düşen \& Oğuz, 2010), R. temporaria (Walton, 1933; Buchvarov, 1977; Kirin \& Buchvarov, 2002), P. fuscus (Walton, 1933), R. kurtmuelleri (Hristovski et al., 2006), A. fragilis (Schad et al., 1960, Shimalov et al., 2000; Sharpilo, 2003; Borkovcová \& Kop-řiva, 2005; Düșen et al., 2010b), N. natrix (Schad et al., 1960; Shimalov \& Shimalov, 2000) and 
Vipera berus (Shimalov \& Shimalov, 2000).

Schad et al. (1960) first time reported O. brevicaudatum in Bufo regularis (probably $B$. viridis), B. viridis, $R$. macrocnemis, $R$. ridibunda and A. fragilis from Turkey. Sharpilo (2003) pointed out that $O$. brevicaudatum has a great disperse in A. fragilis in the Caucasian Region. Oxysomatium brevicaudatum was observed in two toads species in this study. The geographic range of $O$. brevicaudatum Europe and Asia (Yamaguti, 1961).

Specimens deposited: ZDEU HEL-9/2009 (2 Slides)

Family: Echinorhynchidae

Acanthocephalus ranae (Schrank, 1788) Lühe, 1911

Prevalence, intensity and range: Three of 6 hosts were infected $(50 \%, 18.30 .50 \pm 11.54 \mathrm{SD}, 5-25)$.

Other reported hosts: Rana sp., Bombinator sp., Hyla sp., Triturus sp., Salamandra sp., Diemictylus viridescens (Yamaguti, 1963), B. bombina (Buchvarov, 1977; GrabdaKazubska \& Lewin, 1989; Y1ldırımhan et al., 2001a); B. variegata (Grabda-Kazubska \& Lewin, 1989); B. viridis (Buchvarov, 1977; Y1ldırımhan, 1999a; Vashetko \& Siddikov, 1999; Shimalov \& Shimalov, 2001); B. calamita (Shimalov \& Shimalov, 2001); H. Arborea (Düşen \& Öz, 2004), R. arvalis, $R$. dalmatina (Buchvarov, 1977; Düşen et al, 2009); R. temporaria (Buchvarov, 1977; Cedhagen, 1988; Kuc \& Sulgostowska, 1988b); R. esculenta (Buchvarov, 1977; Kuc \& Sulgostowska, 1988b); R. macrocnemis (Yildırımhan et al., 1997a; Yildırımhan et al., 2006b; Düşen, 2007); R. camerani (Yıldırımhan et al., 2006a), Mertensiella caucasica (Yıldırımhan et al., 2001b; 2005b); R. kurtmuelleri (Hristovski et al., 2006); Anguis fragilis (Shimalov et al., 2000). N. natrix (Yamaguti, 1963; Shimalov \& Shimalov, 2000). Also, A. ranae was reported in $R$. ridibunda from different researchers in Turkey (Oğuz et al., 1994; Yıldırımhan et al., 1996; Yıldırımhan et al., 2005a; Düşen \& Öz, 2006; Sağlam \& Arıkan, 2006; Düşen \& Oğuz, 2010).

The geographic range of Acanthocephalus ranae, Europe, U.S.A., Russia (Yamaguti, 1963); Turkey (Oğuz et al., 1994).

Specimens deposited: ZDEU HEL-3/2008

Bufo (Pseudepidalea) viridis (Laurenti, 1768)

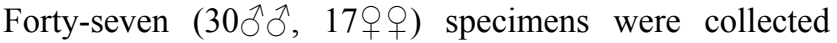
between 2006-2009 years from Denizli province, Turkey $\left(38^{\circ} 29^{\prime}-38^{\circ} 52^{\prime} \mathrm{N}-28^{\circ} 38^{\prime}-30^{\circ} 05^{\prime} \mathrm{E}\right)$.

Family: Polystomatidae

Polystoma viridis Euzet, Combes, and Batchvarov, 1974

Prevalence, intensity and range: Eight of 47 hosts infected $(17.02 \%, 4.50 \pm 2.72 \mathrm{SD}, 1-8)$.

Polystoma viridis is commonly parasitic in the intestine of $B$. viridis, which it is reported from different localities such as Bulgaria (Buchvarov, 1977), Turkey (Yıldırımhan, 1999a; Düşen 2003, Düşen et al., 2010a), Jordan (AlSorkhy \& Amr, 2003) and Iran (Masshaii et al., 2008). The geographic range of $P$. viridis is Europe and the Middle East (Buchvarov, 1977).

Specimens deposited: ZDEU HEL-1/2008
Family: Nematotaeniidae

Nematotaenia dispar (Goeze, 1782) Lühe, 1899

Prevalence, intensity and range: Ten of 47 hosts infected $(21.27 \%, 1.9 \pm 0.99 \mathrm{SD}, 1-4)$.

Nematotaenia dispar is commonly parasitic in the intestines of amphibians, but rarely reptiles, of the Oriental, Nearctic, and Palearctic regions (Prudhoe \& Bray, 1982), including B. bombina (Buchvarov, 1977), B. variegata (Buchvarov, 1977; Prudhoe \& Bray, 1982), B. bufo (Prudhoe \& Bray, 1982), B. alvarius (Goldberg \& Bursey, 1991), H. arborea (Buchvarov, 1977; Prudhoe \& Bray, 1982; Vashetko \& Siddikkov, 1999; Saeed et al., 2007), H. savignyi (Al-Sorkhy \& Amr, 2003; Mashaii, 2005), $R$. ridibunda, $R$. temporaria (Buchvarov, 1977), Mertensiella caucasica (Y1ldırımhan et al., 2001b; 2005b), and Amietophrynus (Bufo) regularis (Ibrahim, 2008). Nematotaenia dispar has been reported from $B$. viridis in Turkey (Yıldırımhan, 1999; Düşen, 2003 \& Düşen et al., 2010a; Düşen \& Oğuz, 2010), Bulgaria (Buchvarov, 1977), Iran (Masshaii et al., 2008), and Iraq (Saeed et al., 2007).

Specimens deposited: ZDEU HEL-2/2008

Family: Rhabdiasidae

Rhabdias bufonis (Schrank, 1788) Stiles and Hassal, 1905

Prevalence, intensity and range: Hosts infected, 24 of 47 (51.06 \%, $8.87 \pm 11.89$ SD, $1-53)$.

Specimens deposited: ZDEU HEL-5/2009 (2 Slides)

Family: Molineidae

Oswaldocruzia filiformis (Goeze, 1782) Travassos, 1917

Prevalence, intensity and range: Fifteen of 47 hosts infected $(31.91 \%, 4.60 \pm 5.06 \mathrm{SD}, 1-20)$.

Specimens deposited: ZDEU HEL-6/2009 (2 Slides)

\section{Family Cosmocercidae}

Cosmocerca commutata (Diesing 1851)

Prevalence, intensity and range: Fourteen of 47 hosts infected $(29.78 \%, 10.28 \pm 9.65 \mathrm{SD}, 1-30)$.

Other reported hosts of C. commutata: Bufo marinus, Hyla luteus, H. tschudii, Leptodactylus typhonius, B. viridis, $R$. esculenta, S. atra, and T. cristatus (Walton, 1933), T. alpestris, $B$. variegata, $P$ syriacus, $P$. fuscus, and $R$. graeca (Buchvarov, 1977), Hyla arborea (Walton, 1933; Düşen \& Öz, 2004), R. dalmatina (Buchvarov et al., 1975; Buchvarov, 1977), $R$. ridibunda (Buchvarov, 1977; Düşen \& Öz, 2006), B. bombina, Bufo bufo, S. salamandra, P. fuscus, and R. temporaria (Walton, 1933; Buchvarov, 1977), Neurergus strauchii (Y1ldırımhan, 2007).

C. commutata is commonly parasitic in the intestine of $B$. viridis, reported from different localities from Bulgaria (Buchvarov, 1977), Turkey (Schad et al., 1960; Yildırımhan 1999, Düşen 2003, Düşen et al., 2010), Jordan (AlSorkhy \& Amr, 2003) and Iran (Masshaii et al., 2008). The geographic range of C. commutata is Europe (Yamaguthi, 1961), Turkey (Yıldırımhan, 1999).

Specimens deposited: ZDEU HEL-7/2009 
Cosmocerca ornata (Dujardin, 1845)

Prevalence, intensity and range: Twenty-three of 47 hosts were infected $(48.93 \%, 8.91 \pm 7.49 \mathrm{SD}, 1-28)$. Specimens deposited: ZDEU HEL-7/2009 (2 Slides)

Oxysomatium brevicaudatum (Zeder, 1800) Railliet and Henry, 1916

Prevalence, intensity and range: Eightteen of 47 hosts were infected $(38.29 \%, 14.22 \pm 11.52 \mathrm{SD}, 2-40)$.

Specimens deposited: ZDEU HEL-9/2009 (2 Slides)

Eight helminth species were found infecting both $B$. bufo and $B$. viridis. The site of infection in the toads and the data on infection parameters for each host and species, are shown in Table 1. In summary, 71 individuals of 5 helminth species were collected from the six B. bufo examined. Nematodes were observed in large-small intestines, lungs and rectum; Acanthocephala was also observed in small intestine of this species. According the data obtained $5(83.33 \%)$ B. bufo harbored the one or more species of parasite and the remaining $1(16.67 \%)$ were uninfected. There were $2.5 \pm 0.57$ helminth species per infected host and there were $18 \pm 14.15$ helminth individuals per infected host.

Forty-seven B. viridis were examined, 907 individuals of 7 helminth species were observed. Nematodes were recorded in lungs, large and small intestines and of this species. Cestoda was observed in large and small intestines; Monogenea was observed in urinary bladder of $B$. viridis. Of the infected $B$. viridis, $46(97.87 \%)$ harbored more species of parasites; the remaining $1(2.13 \%)$ toad were uninfected. There were $2.96 \pm 0.95$ helminth species per infected host and $25.67 \pm 18.37$ helminth individuals per infected host. Four helminths were observed in both bufonid toads. ( $R$. bufonis, O. filiformis, C. ornata, and O. brevicaudatum. The helminths that were observed in two bufonid toads species are common parasites of European anurans (Yamaguthi, 1961; 1963; Buchvarov, 1977; Anderson, 2000; Yıldırımhan, 1999; Yıldırımhan et al., 2007, Düşen \& Öz, 2006, Düşen et al., 2010a).

These results reinforce the importance of carrying out furture studies, because, more helminthological studies are required in Turkey and these studies should also expand the host-parasite list of Turkish amphibians.

\section{Acknowledgements}

This study was supported by TÜBİTAK (The Scientific and Technical Research Council of Turkey) Project no: 107T917, and partly supported by the Pamukkale University Scientific Research Projects Unit Project no: 2008BSP005. I also thank, for permission and helps, the Department of National Parks and Wildlife of the Ministry of Environment and Forestry, of the Republic of Turkey.

\section{References}

AL-SorkHY, M. K., AMr, Z. (2003): Helminth parasites of some amphibians in Jordan. Turk. J. Zool., 27: 89 - 93

ANDERSON, R. C. (2000): Nematode Parasites of Vertebrates: Their Development and Transmission (2nd Edition). CABI Publishing,Wallingford, Oxon, U.K., 650 pp.

BAKER, M. R. (1987): Synopsis of the Nematoda parasitic in amphibians and reptiles. Memorial University of Newfoundland, Occas. Pap. in Biol., 1: $1-325$

BARAN, I., ATATÜR, M. K. (1997): Turkish Herpetofauna. The Republic of Turkey, Ministry of Environment Publications, Ankara. 214 pp.

Bertman, M., OKulEwicz, A. (1987): Lizards (Anguis fragilis L.) and snakes (Natrix natrix (L.)) as new hosts of Oswaldocruzia filiformis (Goeze, 1782) Travassos 1917 (Nematoda). Wiadomosci Parazytol., 33 (2): 209 - 12 (In Polish)

Biserkov, V., Kostadinova, A. (1998): Intestinal helminth communities in the green lizard, Lacerta viridis, from Bulgaria. J. Helminthol., 72 (3): 267 - 271

BorkovcovÁ, M. KopřIVA, J. (2005): Parasitic helminths of reptiles (Reptilia) South Moravia (Czech Republic). Parasitol. Res., 96: $77-78$

BožKov, D., StojkovA, R. (1970): Beitrag zur untersuchung der Helminthenfauna der Rana graeca in Bulgarien. Bulletin de L'institute de Zoologie et Musée, Academie Bulgare des Sciences, 69 - 75 (In Bulgarian)

Buchvarov, G. K. (1977): Catalogue des helminthes des Amphibies en Bulgarie - Universite de Plovdiv "P Hilendarski”, Plovdiv, Bulgaria, 53 pp. (In Bulgarian).

Buchvarov, G. K., Petrov, P., Chochev, B. (1975): To the question about helminthofauna of Amphibious Eucaudate (Amphibia-Eucaudata) of Velingrad's District. Universite de Plovdiv "P Hilendarski”, Travaux Scientifiques, Biologie, 13 (4): 53 - 64

BuDAK, A., GÖÇMEN, B. (2008): Herpetology (Herpetoloji) Ege Üniversity Press, Science Faculty Publ. no: 194 (2nd Edition) 226 pp. (In Turkish)

Cedhagen, T. (1988): Endoparasites in some Swedish amphibians. Acta Parasitol., 33: 107 - 113

DÜŞEN, S. (2003): The helminth fauna of tailless frog species (Ordo: Anura) distributed in Antalya. PhD thesis, Akdeniz University, Antalya, Turkey. 116 pp.

DÜŞEN S., Öz, M. (2004): Helminth parasites of the tree frog, Hyla arborea (Linnaeus, 1758) (Anura: Hylidae) from Southwest Turkey. Comp Parasitol., 71 (2): $258-261$

DÜŞEN S., ÖZ, M. (2006): Parasitic helminths of the marsh frog, Rana ridibunda Pallas, 1771 (Anura: Ranidae), from Antalya Province, south-west Turkey. Comp Parasitol., 73 (1): $121-129$

DÜŞEN, S. (2007): Helminths of the two mountain frogs, Banded frog, Rana camerani Boulenger, 1886 and Uludağ Frog Rana macrocnemis Boulenger, 1885 (Anura: Ranidae), collected from Antalya Province. Acta Parasitol. Tur., 31 (1): $84-88$ 
Düşen, S., UĞURTAŞ, İ. H., AydoĞdu, A., OĞUZ, M. C. (2009): The helminth community of the Agile frog, Rana dalmatina Bonaparte, 1839 (Anura: Ranidae) Collected from Nortwest of Turkey. Helminthologia, 46 (3): 177 - 182 Düşen, S., OĞUz, M. C., Barton, D., P. Aral, A., ŞuleKoĞLU, S., TePE, Y. (2010a): A Metazoan Parasitological Research of Three Species of Anurans Collected from the Çanakkale Province, Northwestern Turkey. North-West J. Zool., 6 (1): 25 - 35

Düşen, S., UĞURTAŞ, İ. H., AYdoĞDU, A. (2010b): Nematode Parasites of the Two Limbless Lizards: Turkish Worm Lizard, Blanus strauchi (Bedriaga, 1884) (Squamata:Amphisbaenidae) and Slow Worm, Anguis fragilis Linnaeus 1758 (Squamata: Anguidae), from Turkey Helminthologia, 47 (3): 158 - 163.

DüşEN, S., OĞUZ, M. C. (2010): Metazoan Endoparasites of Three Species of Anurans Collected from the Middle Black Sea Region of Turkey. Helminthologia, 47 (4): 226 - 232

GRABDA-KAZUBSKA, B., LEWIN, J. (1989): The helminth fauna of Bombina bombina (L.) and Bombina variegata (L.) in Poland. Acta Parasitol., 34: 273 - 279

Frost, D. R., Grant, T., Faivovich, J., Bain, R. H., HaAs, A., Haddad, C. F. B., De Sa, R. O., Channing, A., Wilkinson, M., Donnellan, S. C., RaXworthy, C. J., Campbell, J, A., Blotto, B. L., Moler, P., Drewes, R. C., Nussbaum, R. A., Lynch, J. D., Green, D. M., WhEELER, W. C. (2006): The amphibian tree of life--Bull. American Mus. Nat. Hist., New York; 297: 1 - 370

Hristovski, N., Smilkov, S., TomovskA, D., Popovich E., Kostich, D. (2006): Helmintofauna of Rana kurtmuelleri Gayda, 1940 syn. Rana balcanica Shneider et Sinish, 1992 (Anura:Ranidae) from Dojran Lake, Makedonia and Greece. $10^{\text {th }}$ International Congress on the Zoogeography and Ecology of Greece and Adjacent Regions Patras, Greece. June $26-30$.

IUCN (2010): IUCN Red List of Threatened Species. Downloaded on 11 April 2011 from www.iucnredlist.org IBRAHIM, M. M. I. (2008): Helminth infracommunities of the maculated toad Amietophrynus regularis (Anura: Bufonidae) from Ismailia, Egypt. Dis. Aquat. Org., 82: 19- 26 KIRIN, D. (2002a): New data on the helminth fauna of Lacerta viridis Laurenti, 1768, and Podarcis muralis (Laurenti, 1768) (Reptilia: Lacertidae) in Bulgaria. Acta Zool. Bulg., 54 (1): $43-48$

KIRIN, D. (2002b): New records of the helminth fauna from grass snake, Natrix natrix L., 1758 and dice snake, Natrix tessellata Laurenti, 1768 (Colubridae: Reptilia) in South Bulgaria. Acta Zool. Bul., 54: 49 - 53

KIrIN, D., Buchvarov, G. (2002): Biodiversity of of the helminth communities of acaudated Amphibians (Amphibia: Ecaudata) from Bistritsa Riverside (Gotse Delchev Region). Exp. Pathol. Parasitol., 5(8): 13 - 16

KIRIN, D. (2003a): Biodiversity and ecological particulars of the helminth communities in Rana ridibunda Pallas, 1771, from districts of town Saedinenie. Exp. Pathol. Parasitol., 6 (11): $31-36$

KIRIN, D. (2003b): Biological diversity and ecological measurements of the helminth communities of Rana ridibunda from District of Town Vidin. Exp. Pathol. Parasitol., 6 (11): $37-43$

Kuc, I., Sulgostowska, T. (1988a): Helminth fauna of Rana ridibunda Pallas, 1771 from Goclawski Canal in Warszaw (Poland). Acta Parasitol., 33: 101 - 105

KuC, I., SulgostowsKA, T. (1988b): Helminth fauna of frogs in the forest of Kampinos near Warszawa. Acta Parasitol., 33: $267-272$

MasshaiI, N., Balouch, M., Mobedi, I. (2000): New records about helminth parasites of the marsh frog, Rana ridibunda (Anura: Ranidae), from the North of Iran. Iran. J. Fish. Sci., 2: $77-88$

MAsHAII, N. (2005): Helminth Parasites of green toad, Bufo viridis (Anura: Bufonidae), Tree frog, Hyla arborea savignyi (Anura: Hylidae) and Marsh Frog, Rana ridibunda ridibunda (Anura: Ranidae) from Southwest of Iran. Iran. J. Vet. Res., 6 (3): $67-73$

Masshail, N., Balouch M., Mobedi, I (2008): Report about helminth parasites of some Amphibians (Anura: Ranidae, Bufonidae) from the North and Northeast of Iran. J. Sci. Univ. Tehran., 33 (4): 9 - 13

Mihalca, A. D., Gherman, C., Ghira, I., Cozma, V. (2007): Helminth parasites of reptiles (Reptilia) in Romania. Parasitol. Res., 95: $77-78$

OĞUZ, M. C., Altunel, F. N., UĞURTAŞ, İ. H. (1994): An investigation of the species of Plathelminthes and Acanthocephalus ranae (Schrank, 1788, Acanthocephala) of marsh frogs (Rana ridibunda Pallas, 1771) which were collected from the Bursa and Edirne Regions. Turk J. Zool., 18: 47 - 51 (In Turkish, with English abstract)

PrudhoE, S., A. BRAY, S. (1982): Platyhelminth Parasites of Amphibia. British Museum of Natural History. Oxford University Pres, London. 217 pp

Saeed, I. E., Al-Barwari S., Al-Harmni, K. I. (2007): A metazoan parasitological research of some Iraqi Amphibians. Acta Parasitol. Tur., 3 (4): 337 - 345

SAĞlAM, N., ARIKAN, H. (2006): Endohelminth parasites of the Marsh Frog Rana ridibunda from Hazar Lake, Turkey. Dis. Aquat. Org., 73: $253-260$

Sanchis, V., Roig, J. M., Carretero, M. A., RocA, V., Llorente, G. A. (2000): Host - parasite relationships of Zootoca vivipara (Sauria: Lacertidae), in Pyreenes, North Spain. Folia Parasitol., 47: 118 - 122

Schad, G. A., Kuntz, R. E., Wells, W. H. (1960): Nematode parasites from Turkish vertebrates: an annotated list. Can. J. Zoolog., 38: 949 - 963

Sharpilo V. P., Biserkov, V., Kostadinova, A., BeHnKe, J. M., KuZMin, Y. I. (2001): Helminths of the sand lizard, Lacerta agilis (Reptilia, Lacertidae), in the Palaearctic: faunal diversity and spatial patterns of variation in the composition and structure of component communities. Parasitology, 123: $389-400$

SHARPILO, V. P. (2003): Rare and locally distributed palearctic species of the reptile parasitic worms: Oxysomatium caucasicum (Nematoda, Cosmocertidae). Vesnik Zool., 37 (5): $69-72$

Shimalov, V. V., Shimalov V. T. (2000): Helminth fauna of snakes (Reptilia, Serpentes) in Belorussian Polesye. 
Parasitol. Res., 86: 340 - 341

Shimalov, V. T., Shimalov, V. V., Shimalov A. V. (2000): Helminth fauna of lizards in the southern part of Belarus. Parasitol. Res., 86: 343

Shimalov, V. V., Shimalov V. T. (2001): Helminth fauna of toads in Belorussian Polesie. Parasitol. Res., 87: 84

Shimalov, V. V., Shimalov, V. T., Shimalov, A. V. (2001): Helminth fauna of newts in Belarusian Polesie. Parasitol. Res., 87: 356

VAn Sluys, M., Schittini, G., Marra, R. V., Azevedo, A., Vicente J. J., VRCIBRADIC, D., (2006): Body size, diet and endoparasites of the microhylid frog Chiasmocleis capixaba in an Atlantic Forest Area of Southern Bahiastate, Brazil. Brazilian Brazil. J. Biol., 66 (1A): 167 - 173 VAshetKo, E. V., Siddikov, B. H. (1999): The effect of the ecology of toads on the distribution of helminths. Turk. J. Zool., 23: 107-110

Walton, A. C. (1933): The nematoda as parasites of Amphibia. J. Parasitol. 20: (1) 1 - 33

YAMAGUTI,, S. (1961): Systema Helminthum: The nematodes of vertebrates. Vol III., Part II. Nematodes of Amphibians. Intersciences Publishers Ltd. London, England 679 pp.

YamaguTI, S. (1963): Systema Helminthum. Acanthocephala. Vol.V. Intersciences Publishers, London, England. $423 \mathrm{pp}$.

Yildirimhan, H. S., UĞURTAŞ, İ. H., Altunel, F. N. (1996): An investigation on helminths of Rana ridibunda Pallas, 1771 (marsh frog). Acta Parasitol. Tur., 20: 113 130 (in Turkish, with English abstract)

YildiRIMHAN, H. S., OĞUZ, M. C., UĞURTAŞ, İ. H. (1997a): An investigation on the nematodes of some tailless frogs (Rana ridibunda, Bufo bufo and Pelobates syriacus) collected from the Bursa regions. Hacettepe Fen ve Müh. Bil. Derg., 18: 45 - 58 (in Turkish with English abstract)

Yildirimhan, H. S., UĞURTaș I. H., Altunel, F. N. (1997b): An investigation on parasitic helminths of Rana macrocnemis Boulenger, 1885 (Uludag frog). Turk J Zool. 21: $467-473$

YILDIRIMHAN, H. S. (1999a): Researches on parasitic helminths of Bufo viridis Laurenti, 1768 (Anura: Amphibia). Turk. J. Zool, 23: $177-195$

YILDIRIMHAN, H. S. (1999b): Helminth fauna of lizards species belonging to Lacertidae (Reptilia) family distributed in Bursa and its around (PhD thesis). Uludağ University, Institute of Science. 120 pp, Bursa (In Turkish, with English abstract)

Yildirimhan, H. S., AYdoĞDU, A., UĞURTAŞ, I. H., Altunel, F. N. (2001a): Helminth fauna of Bombina bombina (Linnaeus, 1767) (Fire-Bellied Toad) collected from Sakarya and Edirne (Turkey). Acta Parasitol. Tur., 25 (3): 308 - 311 (in Turkish, with English abstract)

YILDIRIMHAN, H. S., AYDOĞDU, A., UĞURTAŞ, I. H., AltunEL, F. N. (2001b): An investigation on Plathelminth and Acanthocephala of Mertensiella caucasica (Caucasian Salamander). Acta Parasitol. Tur., 25: 393 - 397 (In Turkish, with English abstract)

YILDIRIMHAN, H. S., KARADENIZ, E., GÜRKAN, E., KoYUN, M. (2005a): Metazoon parasites of the Marsh frog (Rana ridibunda Pallas, 1771; Anura) collected from the different regions in Turkey. Acta Parasitol. Tur., 29 (2): 135 - 139 (In Turkish with English abstract)

Yildirimhan, H. S., Bursey C. R., GoldberG, S. R. (2005b): Helminth parasites of the Caucasian salamander, Mertensiella caucasica, from Turkey. Comparative Parasitology 72(1): $75-87$

Yildirimhan, H. S., Goldberg S. R., Bursey, C. R. (2006a): Helminth parasites of the Banded Frog, Rana camerani (Ranidae) from Turkey. Comparative Parasitology 73(2): 222-236.

Yildirimhan, H. S., Bursey, C. R. GoldberG, S. R. (2006b): Helminth parasites of the Taurus frog, Rana holtzi, and the Uludag frog, Rana macrocnemis, with remarks on the helminth community of Turkish anurans. Comp. Parasitol., 73 (2): 237-248

Yildirimhan, H. S., Altunel F. C., UĞurtaş, I. H. (2006c): Helminth parasites of Hyla arborea (Linneaus, 1758) (Tree Frog) collected from Bursa, Edirne and Sakarya. Acta Parasitol. Tur., 30 (1): 56 - 59 (In Turkish with English abstract)

YILDIRIMHAN, H. S., KARADENIZ, E. (2007): Helminth Parasites of the Common Toad, Bufo bufo (Linnaeus, 1758) (Anura: Bufonidae) from Northeast Turkey. Comp. Parasitol., 74 (1): $176-178$.

YILDIRIMHAN, H. S. 2007. Helminth Fauna of Neurergus strauchii (Steindachner, 1888) (Spotted Salamander) Collected in Malatya and Bitlis. Acta Parasitol. Tur. 31 (2): 229 - 231 (In Turkish with English abstract)

YILDIRIMHAN, H. S. (2008): A Preliminary investigatin on helminth fauna of Triturus vittatus (Jenyns, 1835)) and T. karelinii (Strauch, 1870). Acta Parasitol. Tur. 32 (2): 158 - 160 (In Turkish with English abstract)

Yildirimhan, H. S., Bursey, C. R. GoldBerG, S. R. (2009): Helminth Parasites of the Caucasian Parsley Frog, Pelodytes caucasicus, from Turkey. Comp. Parasitol., 76(2): 247-257 pp

YILDIRIMHAN, H. S., BURSEY, C. R. 2010. Helminth parasites of the eastern spadefoot toad, Pelobates syriacus (Pelobatidae), from Turkey. Turk J Zool. 34: 11 - 319 